\title{
European lobsters utilise Atlantic salmon wastes in coastal integrated multi-trophic aquaculture systems
}

\author{
A. Baltadakis ${ }^{1, *}$, J. Casserly ${ }^{2}$, L. Falconer ${ }^{1}$, M. Sprague ${ }^{1}$, T. C. Telfer $^{1}$ \\ ${ }^{1}$ Institute of Aquaculture, Faculty of Natural Sciences, University of Stirling, Stirling FK9 4LA, UK \\ ${ }^{2}$ Marine Institute, Rinville, Oranmore H91 R673, Ireland
}

\begin{abstract}
In this study, we investigated if juvenile European lobsters Homarus gammarus would eat waste from Atlantic salmon Salmo salar cages in a coastal integrated multi-trophic aquaculture (IMTA) setup and if there were any impacts on growth. Trophic interactions between salmon and lobsters were assessed using $\delta^{15} \mathrm{~N}$ and $\delta^{13} \mathrm{C}$ stable isotope analysis and fatty acid profiling from fish feed as indicators of nutrient flow. Analysis revealed that lobsters directly utilised particulate waste from salmon production, as levels of indicator fatty acids from salmon feed were significantly higher in lobster tissues near the fish cages compared to the control site. Route of uptake may have been direct consumption of waste feed or faecal material or indirectly through fouling organisms. Stable isotope analysis did not indicate nutrient transfer to lobsters, suggesting that the duration of the study and/or the amount of waste consumed was not sufficient for stable isotope analysis. Lobsters grew significantly over the trial period at both sites, but there was no significant difference in lobster growth between the sites. Our results show a trophic relationship between salmon and lobsters within this IMTA system, with no apparent advantage or disadvantage to growth.
\end{abstract}

KEY WORDS: Integrated multi-trophic aquaculture - IMTA - Lobster - Salmon · Fatty acids · Stable isotopes $\cdot$ Ecosystem services

\section{INTRODUCTION}

The European lobster Homarus gammarus (Linnaeus, 1758) is an important economic decapod crustacean, with a natural distribution ranging from Morocco to northern Norway (Wilson 2008). Global demand for lobster is increasing, but over the past few decades wild stocks have been decreasing (Drengstig \& Bergheim 2013, Ellis et al. 2015, Nillos Kleiven et al. 2019), prompting research into commercial hatchery production of larvae for restocking purposes (Addison et al. 1994, Schmalenbach et al. 2011). However, lobsters grown in land-based hatcheries and then directly released into the environment are known to be vulnerable to immediate predation as they have limited exposure to environmental stimuli

\footnotetext{
*Corresponding author: tasosbaltak@gmail.com
}

(Agnalt et al. 2017). To improve survivability, seabased containers have been used successfully to acclimatise juvenile lobsters to environmental conditions before final release (Beal et al. 2002, Perez Benavente et al. 2010, Beal \& Protopopescu 2012, Daniels et al. 2015, Halswell et al. 2016). At the release stage, juvenile lobsters form small burrows in sediment and feed on zooplankton and organic matter particles suspended in the water column, using currents created by their pleopods (swimmerets). The particle sizes consumed at this stage are normally between 60 and $100 \mu \mathrm{m}$ (Lavalli \& Barshaw 1989), suggesting that they are able to consume fine particulate wastes from fish farms.

Atlantic salmon Salmo salar cage farms are generally sited in coastal environments and release nutrient-

() The authors 2020. Open Access under Creative Commons by Attribution Licence. Use, distribution and reproduction are unrestricted. Authors and original publication must be credited. 
rich particulate and dissolved wastes such organic carbon and nitrogen from uneaten food and faecal wastes and excreted soluble nitrogen into the surrounding environment (Wang et al. 2012). The concept of integrated multi-trophic aquaculture (IMTA) endeavours to utilise these wastes, thereby increasing the resource efficiency of trophically linked co-cultured species to improve nutrient utilisation for environmental mitigation while producing additional organisms (Chopin et al. 2012). Placing lobsters in seabased containers next to fish cages may provide a regular food supply, together with other potentially beneficial conditions (e.g. shelter, co-location for efficiency improvements), for improved growth and management. This may also function as an ecosystem service from salmon aquaculture and provide positive societal benefits; for example, if there is improvement of growth and better survival when released, it could aid enhancement of local lobster populations and any resulting fishery.

Performance of IMTA can be measured empirically by comparing growth or nutrient uptake by the consumer species between the culture site and a reference location. This approach has been used to assess shellfish growth (Sarà et al. 2009, Lander et al. 2013) and nutrient uptake and growth of seaweeds (Blouin et al. 2007, Abreu et al. 2009). Direct nutrient transfer between species is commonly investigated using biochemical tracers, such as fatty acids (FAs) and stable isotopes (Redmond et al. 2010, Colombo et al. 2016, White et al. 2019, Sardenne et al. 2020).

FAs have been used to assess the dispersal of particulate-derived waste, both spatially and through food webs, with studies assessing the level of influence aquaculture has on wild fish and benthic communities (e.g. Fernandez-Jover et al. 2009, 2011, White et al. 2017, 2019, Woodcock et al. 2018). However, assessing the performance of an IMTA system with FAs is dependent on the target species, as there have been variable results using blue mussels Mytilus edulis (Redmond et al. 2010, Irisarri et al. 2015), although more consistency has been found for zooplankton (Fernandez-Jover et al. 2009), shrimp (Olsen et al. 2012) and sea urchins (George \& Parrish 2015).

Stable isotopes of carbon and nitrogen have been used widely to assess the flow of nutrients through food webs, and more recently, to trace waste products from aquaculture (Marín Leal et al. 2008, Deudero et al. 2012). Stable isotopes assimilate within the tissues of consumers, with heavier isotopes, ${ }^{13} \mathrm{C}$ and ${ }^{15} \mathrm{~N}$, remaining longer in animal tissues than lighter ones, ${ }^{12} \mathrm{C}$ and ${ }^{14} \mathrm{~N}$, which are rapidly utilised during metabolism (Marín Leal et al. 2008). Consequently, the tissues of organisms tend to adopt the same stable isotopic signature as their food source (Paulet et al. 2006). $\delta^{13} \mathrm{C}$ and $\delta^{15} \mathrm{~N}$ ratios have been applied for nutrient tracking within IMTA systems with fish and mussels in the Bay of Fundy, Canada (Irisarri et al. 2015), fish with oysters and mussels (Navarrete-Mier et al. 2010) and in multiple farms with fish and mussels in the Western Mediterranean (Sanz-Lazaro \& Sanchez-Jerez 2017).

The aim of this study was to investigate if juvenile European lobsters would consume wastes from salmon cages by assessing the nutrient transfer between salmon waste and lobsters within a pilot-scale coastal site and whether there were any positive or negative effects on growth. FA analysis and stable isotopes were used as tracers of nutrient transfer, and growth was determined as an increase in carapace length (CL).

\section{MATERIALS AND METHODS}

\subsection{Experimental site and data collection}

The study was conducted at the Lehanagh Pool marine research site, a small-scale experimental IMTA site in Bertraghboy Bay, Connemara, County Galway, Ireland (Fig. 1), between January 2018 and March 2019. The site comprised 2 polar circle cages $(50 \mathrm{~m}$ circumference and $8 \mathrm{~m}$ deep) at a water depth of $21 \mathrm{~m}$. These were stocked in April 2018 with 7660 Atlantic salmon post-smolts (5360 and 2300 in the 2 cages), averaging 90 to $100 \mathrm{~g}$. In addition, 400 lumpfish Cyclopetrus lumpus, averaging 40-50 g, were also stocked into each cage as a preventative method for controlling sea lice as per commercial standards. The fish were hand-fed a maintenance diet according to the manufacturer's feeding tables. The site was managed according to organic farm standards, with no prescription medicines or antifoulants used. A control site for the study was set up approximately $300 \mathrm{~m}$ west of the cages. European lobsters (Stage IV juveniles, $\mathrm{n}=204$ ) were deployed in May 2018 (108 at the cage site, 96 at the control site) within sea-based container culture (SBCC) structures (see Daniels et al. 2015). Lobsters (n = 36) were housed individually and labelled in each stack suspended from the cages at $2 \mathrm{~m}$ depth and from a longline at the control site at the same depth.

Particulate organic matter loading from the salmon cages was modelled with a spreadsheet-based particulate dispersion model (Telfer et al. 2006) to assess the organic load dispersal and deposition around the cages and ensure that the SBCC structures were situated in locations where the lobsters would be exposed to salmon waste and that the control site was far enough 
away not to be influenced by particulate wastes. The model was run using data from fish production and measured current speeds and directions collected using a MIDAS ECM self-recording electromagnetic current meter (Valeport) deployed at 2 depths (9 and $14 \mathrm{~m}$ ) within $50 \mathrm{~m}$ of the cages between 1 and 15 July 2018.

During this time, 3 sediment traps were positioned to assess the numerical and distributional accuracy of the model. Two sediment traps were placed at a depth of $19 \mathrm{~m}$, one $0 \mathrm{~m}$ and one $5 \mathrm{~m}$ from the south-west cage; the latter was between the 2 cages. The third sediment trap was deployed at the control site at $5 \mathrm{~m}$ depth. Each sediment trap had 4 cylinders with a height:diameter ratio 7.5:1 (60:8 cm) secured vertically on a gimballed stainless steel frame. A clear container (plastic fixed pot) was

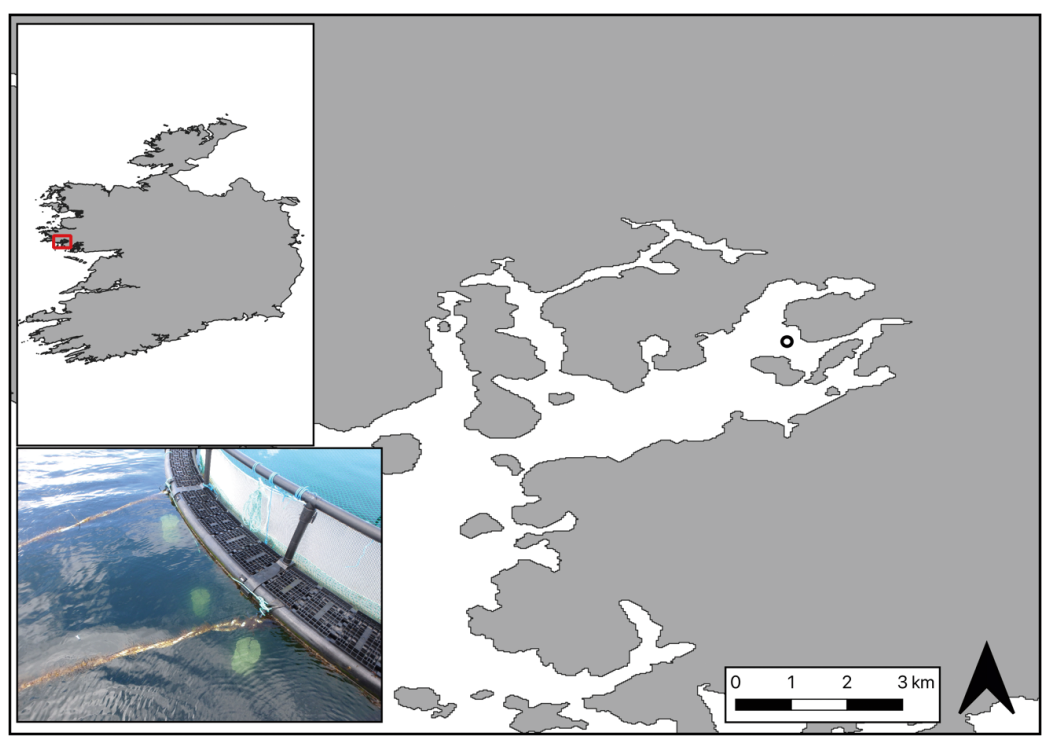

Fig. 1. Bertraghboy Bay, Ireland, and the location of the marine research site. The photograph shows the cage site and the sea-based container culture (SBCC) structures. The black circle indicates the location of the experimental site in relation to the Irish West Coast

A von Bertalanffy growth curve (von Bertalanffy 1938) was fitted to the mean CL measurements during the trial:

$$
L(t)=L \infty\left\{1-\exp \left[-K\left(t-t_{0}\right)\right]\right\}
$$

where $L(t)$ is CL (mm) as a function of time $(t), L \infty$ is the largest lobster $\mathrm{CL}$, and $K$ is the growth coefficient $\left(\mathrm{yr}^{-1}\right)$.

\subsection{Lipid and FA analysis}

Lobsters were deployed in SBCCs at the cage site at the beginning of April 2018, and growth measurements commenced after a period of 1 mo. Growth of lobsters was assessed by measuring CL (mm) on 9 occasions over a 319 d period, between May 2018 and March 2019. Due to variable weather conditions, between 20 and 60 lobsters were randomly subsampled from the cage and control sites, at each sampling event. Each lobster was removed from the SBCC unit and placed on gridded paper. A digital image was taken at 90 degrees to each specimen. The lobster was then returned to its container and to the water. CL was measured from the images using Digimizer image analysis software (MedCalc Software).

CL gain (CLG) was used as an indicator of growth at the cage and control sites and was calculated as:

$$
\mathrm{CLG}=\mathrm{CL}_{t}-\mathrm{CL}_{0}
$$

where $\mathrm{CL}_{t}$ is final $\mathrm{CL}$ and $\mathrm{CL}_{0}$ is initial CL.
At the end of the trial (March 2019), 20 juvenile lobsters were sampled and stored in a freezer $\left(-20^{\circ} \mathrm{C}\right)$ overnight. The next day, samples were shipped on ice to the University of Stirling for analysis. Ten individual juvenile lobsters from the control and 10 from the cage location, and a sample of the salmon aquafeed used at the cage site were individually homogenised and subjected to lipid extraction.

Total lipids were extracted from $0.5-1.0 \mathrm{~g}$ of feed and lobster tissue in ice-cold chloroform:methanol solution (ratio 2:1, v/v). Extraction of lobster tissue was achieved using $20 \mathrm{ml}$ of solution and feed using $36 \mathrm{ml}$ of solution. The samples were homogenised in an Ultra-Turrax tissue disruptor (Fisher Scientific). Lipid content was determined gravimetrically (Folch et al. 1957).

FA methyl esters (FAMEs) were separated from total lipids by acid-catalysed transmethylation at $50^{\circ} \mathrm{C}$ 
for $16 \mathrm{~h}$ using $2 \mathrm{ml}$ of $1 \%$ (v/v) sulphuric acid (95\%, Aristar®, BDH Chemicals) in methanol and $1 \mathrm{ml}$ toluene (Christie 1993). FAMEs (6 ml) were extracted and purified by adsorption chromatography using $500 \mathrm{mg}$ sorbent acid washed solid-phase extraction cartridges (Clean-up® silica extraction columns; UCT). Cartridges were pre-conditioned with $5 \mathrm{ml}$ of isohexane before the sample was added and the FAMEs eluted with $10 \mathrm{ml}$ isohexane:diethyl ether (95:5, v/v) and separated and quantified by gas-liquid chromatography using a Fisons GC-8160 (Thermo Scientific) equipped with a $30 \mathrm{~m} \times 0.32 \mathrm{~mm}$ i.d. $\times 0.25 \mu \mathrm{m} \mathrm{ZB}$-wax column (Phenomenex). Hydrogen was used as the carrier gas with an initial oven gradient of 50 to $150^{\circ} \mathrm{C}$ at $40^{\circ} \mathrm{C} \mathrm{min}^{-1}$ to a final temperature of $230^{\circ} \mathrm{C}$ at $2^{\circ} \mathrm{C} \mathrm{min}^{-1}$. Individual FAMEs were identified by comparison to standards (Supelco ${ }^{\mathrm{TM}} 37$ - FAME mix; Sigma-Aldrich). All data were collected and processed using ChromCard $^{\mathrm{TM}}$ for Windows (Version 1.19; Thermoquest Italia) software. 17:0 heptadecanoic acid was used as internal standard to calculate FA content per $g$ of tissue.

Predominant FAs measured within the salmon feed were used as tracers. A total of 5 FAs were selected. Three FAs, oleic acid (OA, 18:1n-9), linoleic acid (LA, 18:2n-6) and $\alpha$-linolenic acid (ALA, 18:3n-3), were based on the increased 'terrestrial' FAs derived from an increasing inclusion level of vegetable oil used within salmon feed (Sprague et al. 2016). Cetoleic acid (22:1n-11) and eicosenoic acid (20:1n-9) were also chosen, as they tend to be typically found in higher quantities within salmon feed and have consequently been observed in fish farm waste (Henderson et al. 1997).

\subsection{Stable isotope analysis}

Five samples of lobster leg muscle from each site ( $\mathrm{n}=5$ control site, $\mathrm{n}=5$ cage site) and 2 samples of salmon feed were subjected to stable isotope analysis. Each sample was frozen at $-20^{\circ} \mathrm{C}$ prior to lyophilisation in a Christ Alpha 1-4 LSC freeze-drier (Martin Christ Gefriertrocknungsanlagen). For the analysis, $0.7 \mathrm{mg}$ of lobster leg muscle and $1.5 \mathrm{mg}$ of feed were weighted into $3 \times 5 \mathrm{~mm}$ tin capsules and loaded onto an Elementar Procure analyser, which converted organic $\mathrm{N}$ and $\mathrm{C}$ in the samples to $\mathrm{N}_{2}$ and $\mathrm{CO}_{2}$ for measurement of $\delta^{15} \mathrm{~N}$ and $\delta^{13} \mathrm{C}$, respectively, on a Thermo-Fisher-Scientific Delta XP Plus isotope ratio mass spectrometer.

Units of isotope ratios were expressed in $\delta^{15} \mathrm{~N}$ and $\delta^{13} \mathrm{C}$ :

$$
\delta X=\left[\left(\frac{R_{\text {sample }}}{R_{\text {standard }}}\right)-1\right] \times 1000
$$

where $X$ is ${ }^{13} \mathrm{C}$ or ${ }^{15} \mathrm{~N}$, and $R$ is either the ${ }^{13} \mathrm{C}:{ }^{12} \mathrm{C}$ ratio or the ${ }^{15} \mathrm{~N}:{ }^{14} \mathrm{~N}$ ratio. In-house reference materials used were: gelatine solution, alanine-gelatine solution spiked with ${ }^{13} \mathrm{C}$-alanine, and glycine-gelatine solution, each dried for $2 \mathrm{~h}$ at $70^{\circ} \mathrm{C}$. Four USGS 40 glutamic acid standards (Qi et al. 2003, Coplen et al. 2006) were used as independent checks of accuracy.

\subsection{Statistical analyses}

FA percentages for each sample were arcsine transformed prior to statistical analysis to correct for the binomial distribution of proportional data (Sokal $\&$ Rohlf 1995). FAs occupying more than $0.1 \%$ of the feed FA profile were compared between the cage and the control site, using a 2-sample Student's $t$-test. Statistical tests were performed using Minitab ${ }^{\mathrm{TM}}$ statistical software. Principal component analysis (PCA) was used to classify and discriminate between the FA profiles of the lobster samples at different locations. PCA creates 2 orthogonal values (principal components, PCs) which are representative of the original variables. The higher the $\mathrm{PC}$ value is, the more representative of the data set it is. PCA was performed using MVSP statistical software (KCS). A non-parametric multivariate ANOSIM was performed with PRIMER 5 (Clark \& Gorley 2001) to detect significant differences between a priori sources of variation for the cage site and control site results (as defined factors) using a Bray-Curtis similarity matrix.

Stable isotopes $\left(\delta^{13} \mathrm{C}\right.$ and $\left.\delta^{15} \mathrm{~N}\right)$ for lobster leg muscle were compared between the 2 locations using a 2-sample Student's t-test, using Minitab software.

Growth was compared between the 2 locations over time with a repeated-measures ANOVA, using SPSS Ver 26 software (IBM). As sphericity is an important assumption of a repeated-measures ANOVA (where the variances of the differences between all possible pairs of within-subject conditions are equal), the growth data were tested using Mauchly's test of sphericity.

\section{RESULTS}

\subsection{Waste dispersion and current flow at the cage site}

The hydrographic data collected by the current meter showed that the cage site was characterised by moderate to slow average current speeds of $0.040 \mathrm{~m}$ $\mathrm{s}^{-1}$ in mid-water and $0.028 \mathrm{~m} \mathrm{~s}^{-1}$ near the seabed. The 
residual current flow showed a very slow movement in a southerly direction over time. Distribution of particulate waste from the cages over the trial period was very local to the fish cages, with only low amounts of particulate waste travelling beyond $20 \mathrm{~m}$ from the cage edge (Fig. 2).

Model predictions of sedimentation for suspended solids near the SBCC deployment locations (100$200 \mathrm{~g} \mathrm{~m}^{-2} 15 \mathrm{~d}^{-1}$ ) showed broad agreement with average sediment trap-collected material $\left(252 \mathrm{~g} \mathrm{~m}^{-2} 15 \mathrm{~d}^{-1}\right)$. However, the model underestimated the distribution of solid waste between the cages, with modelled values of 50 and $100 \mathrm{~g}$ vs. an average measured value of $368 \mathrm{~g} \mathrm{~m}^{-2} 15 \mathrm{~d}^{-1}$. Both model and sediment traps illustrated that the SBCCs near the cages were placed in areas of high particulate waste distribution of between 100 and $200 \mathrm{~g} \mathrm{~m}^{-2} 15 \mathrm{~d}^{-1}$. The models also showed little possibility that much particulate waste from the cages would reach the control lobster site approximately $300 \mathrm{~m}$ to the west.

\subsection{FAs}

The FA profile of lobster tissues varied with location, as the amount of FA tracers (given as \% of total lipid) showed significant differences $(p<0.05)$ between the cages and control stations (Table 1). Lobsters located near the cages had a significantly higher total lipid content $\left(1.22 \pm 0.34 \mathrm{mg} \mathrm{g}^{-1} \mathrm{DW}\right.$; mean $\left.\pm \mathrm{SD}\right)$ than those at the control site $\left(0.93 \pm 0.19 \mathrm{mg} \mathrm{g}^{-1} \mathrm{DW}\right)$ $(p<0.05)$. The FA profile of the supplemented sal-

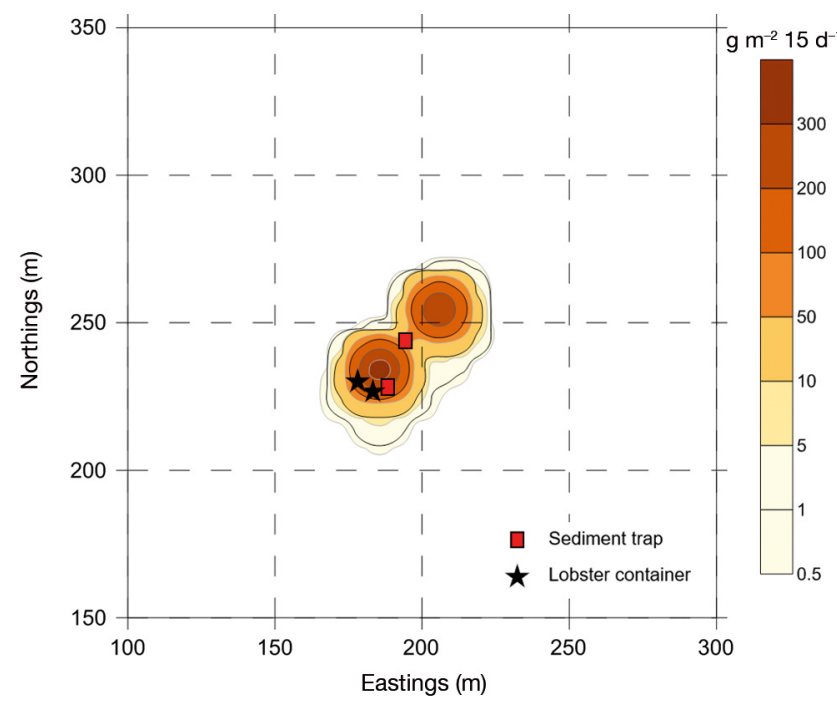

Fig. 2. Contour plot of suspended solids settlement $\left(\mathrm{g} \mathrm{m}^{-2}\right.$ $15 \mathrm{~d}^{-1}$ ) around cages 1 and 2, presented as output from a spreadsheet-based dispersion model mon feed was largely characterised by OA (18:1n-9; $24.4 \%)$, eicosenoic acid $(20: 1 \mathrm{n}-9 ; 7.2 \%)$, cetoleic acid $(22: 1 \mathrm{n}-11 ; 12.8 \%)$, LA $(18: 2 \mathrm{n}-6 ; 11.6 \%)$ and ALA $(18: 3 n-3 ; 4 \%)$, confirming that these FAs are indicative and appropriate for use as tracers. The relative percentages of these FAs were significantly higher $(p<0.05)$ in lobsters located near the cage site (Fig. 3) than in those at the control site. Additionally, n-6 polyunsaturated FA (PUFA) levels were found to be significantly higher at the cage site $(12.24 \pm 0.77 \%)$ compared to the control $(10.27 \pm 0.65 \%)(p<0.05)$, with LA (18:2n-6) being higher in the cage $(6.3 \pm 1.4 \%)$

Table 1. Fatty acid (FA) profile (\% FA of total lipid) of lobster muscle. Values are means $( \pm \mathrm{SD})$. Last column indicates level of significance between the 2 locations $\left({ }^{* * *} \mathrm{p}<0.001\right.$, $\left.{ }^{* *} \mathrm{p}<0.01,{ }^{*} \mathrm{p}<0.05\right)$. PUFA: polyunsaturated FA; DMA: dimethyl acetal. Total saturated FAs also include 15:0, iso17:0, anteiso17:0, iso18:0, anteiso18:0, 22:0 and 24:0; total monoenes also include $16: 1 \mathrm{n}-9,17: 1,20: 1 \mathrm{n}-11,20: 1 \mathrm{n}-7$ and $22: 1 \mathrm{n}-9$; total n-6 PUFAs also include 18:3n-6, 20:3n-6, 22:4n-6 and 22:5n-6; total n-3 PUFAs also include 21:5n-3; total PUFAs also include 16:2, 16:3 and 16:4; total DMA includes 16:0 DMA, 18:0 DMA, 18:1 DMA and 20:0 DMA. NA: not applicable

\begin{tabular}{|c|c|c|c|c|}
\hline & \multirow[t]{2}{*}{ Feed } & \multicolumn{2}{|c|}{ Lobsters -} & \multirow{2}{*}{$\begin{array}{l}\text { Signifi } \\
\text { cance }\end{array}$} \\
\hline & & Cages & Control & \\
\hline Total lipid (\%) & 24.16 & $1.22 \pm 0.34$ & $0.93 \pm 0.18$ & \\
\hline \multicolumn{5}{|l|}{ Fatty acids } \\
\hline $14: 0$ & 4.6 & $1.2 \pm 0.3$ & $0.5 \pm 0.1$ & $* * *$ \\
\hline $16: 0$ & 10.6 & $12.1 \pm 0.5$ & $11.8 \pm 0.5$ & NA \\
\hline 18:0 & 1.5 & $4.6 \pm 0.6$ & $6.8 \pm 0.4$ & $* * *$ \\
\hline $20: 0$ & 0.3 & $0.4 \pm 0.0$ & $0.5 \pm 0.1$ & $* * *$ \\
\hline Total saturated & 17.4 & $19.3 \pm 0.8$ & $20.8 \pm 0.5$ & $* * *$ \\
\hline $16: 1 n-7$ & 3.4 & $3.1 \pm 0.5$ & $2.7 \pm 0.4$ & $*$ \\
\hline $18: 1 n-9$ & 24.0 & $14.6 \pm 1.6$ & $8.4 \pm 0.8$ & $* * *$ \\
\hline $18: 1 n-7$ & 2.0 & $5.2 \pm 0.4$ & $6.3 \pm 0.6$ & $* * *$ \\
\hline $20: 1 n-9$ & 7.2 & $3.4 \pm 0.5$ & $1.5 \pm 0.2$ & $* * *$ \\
\hline $22: 1 n-11$ & 12.7 & $3.9 \pm 1.2$ & $0.1 \pm 0.1$ & $* * *$ \\
\hline $24: 1 \mathrm{n}-9$ & 0.7 & $0.4 \pm 0.1$ & $0.1 \pm 0.1$ & $* * *$ \\
\hline Total monoenes & 51.9 & $33.8 \pm 3.6$ & $21.6 \pm 1.3$ & $* * *$ \\
\hline $18: 2 n-6$ & 11.5 & $6.4 \pm 1.4$ & $0.9 \pm 0.1$ & $* * *$ \\
\hline $20: 2 n-6$ & 0.2 & $1.2 \pm 0.2$ & $1.4 \pm 0.1$ & $*$ \\
\hline $20: 4 n-6$ & 0.3 & $3.6 \pm 0.7$ & $6.6 \pm 0.9$ & $* * *$ \\
\hline Total n-6 PUFAs & 12.0 & $12.2 \pm 0.8$ & $10.3 \pm 0.7$ & $* * *$ \\
\hline $18: 3 n-3$ & 4.0 & $0.8 \pm 0.1$ & $0.5 \pm 0.1$ & $* * *$ \\
\hline $18: 4 n-3$ & 2.0 & $0.6 \pm 0.2$ & $0.4 \pm 0.1$ & $* *$ \\
\hline $20: 3 n-3$ & 0.1 & $0.4 \pm 0.0$ & $0.5 \pm 0.0$ & $* * *$ \\
\hline $20: 4 n-3$ & 0.3 & $0.5 \pm 0.1$ & $0.5 \pm 0.1$ & NA \\
\hline $20: 5 n-3$ & 5.0 & $14.9 \pm 2.0$ & $22.8 \pm 1.0$ & $* * *$ \\
\hline $22: 5 n-3$ & 0.6 & $1.2 \pm 0.2$ & $1.4 \pm 0.8$ & NA \\
\hline $22: 6 n-3$ & 5.5 & $13.8 \pm 1.5$ & $17.3 \pm 1.5$ & $* * *$ \\
\hline Total n-3 PUFAs & 17.8 & $32.3 \pm 3.0$ & $43.3 \pm 1.4$ & $* * *$ \\
\hline Total PUFAs & 30.7 & $44.7 \pm 2.6$ & $54.1 \pm 1.4$ & $* * *$ \\
\hline Total DMA & 0.0 & $2.2 \pm 0.5$ & $3.4 \pm 0.5$ & $* * *$ \\
\hline
\end{tabular}




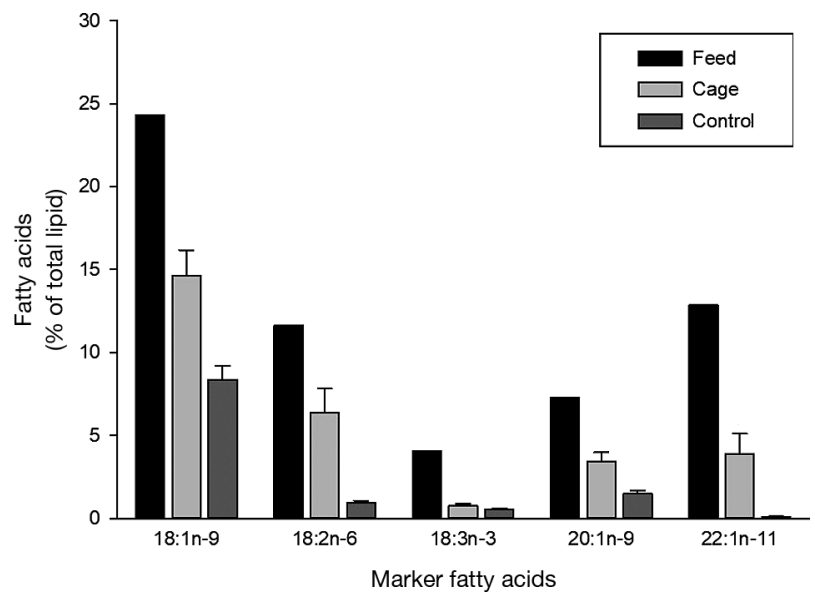

Fig. 3. Contribution of selected fatty acids (\% of total lipid, mean $\pm \mathrm{SD}$ ) to the total fatty acid content in the lobster tissue at the end of the experiment (March 2019) at the control and cage sites. Feed levels are included for reference

compared to the control $(0.9 \pm 0.1 \%)(\mathrm{p}<0.05)$ (see Table 1). Overall, tracer FAs accounted for $29.08 \%$ of the total lipid content of the cage station, which was significantly higher when compared to the control station (11.36\%). Conversely, total n-3 PUFA levels were significantly higher $(\mathrm{p}<0.05)$ at the control site $(43.27 \pm 1.38 \%)$ compared to the cage site $(32.3 \pm 3 \%)$. FA s contributing to the difference between the control and the cage site were eicosapentaenoic acid (EPA, $22.8 \pm 1 \%$ and $14.9 \pm 0.9 \%$ ) and docosa- hexaenoic acid (DHA, $17.2 \pm 1.46 \%$ and $13.8 \pm 1.4 \%$ ), respectively.

The PCA plot (Fig. 4) indicated clear differences between FA profiles of lobster leg muscle from the cage site and from the control site along PC-1, which accounted for $92.8 \%$ of the total variance in the data. Post hoc ANOSIM confirmed the groups from control and cage sites were significantly different $(p<0.05, R=$ 0.994). The FAs primarily driving this difference at the cage site were OA $(18: 1 n-9)$ and LA $(18: 2 n-6)$ of terrestrial origin, along with eicosenoic acid (20:1n-9) and cetoleic acid (22:1n-11). These are marine oilbased, and both were incorporated at high levels within the salmon feed. On the other hand, EPA and DHA together with arachidonic acid (20:4n-6) were more dominant in defining the FA profile at the control site, making it likely that the diet of the lobsters was primarily influenced by naturally derived marine oils, accounting for $40.4 \%$ of total FAs compared to $28.7 \%$ for lobsters at the cages (Table 1).

\subsection{Stable isotopes}

The $\delta^{13} \mathrm{C}$ and $\delta^{15} \mathrm{~N}$ signatures for lobster tissue at the control and cage sites were similar, as shown by their similar positions in the plot (Fig. 5). However, the signature for salmon feed differed from those found for lobsters (Fig. 5). A 2-sample Student's t-test

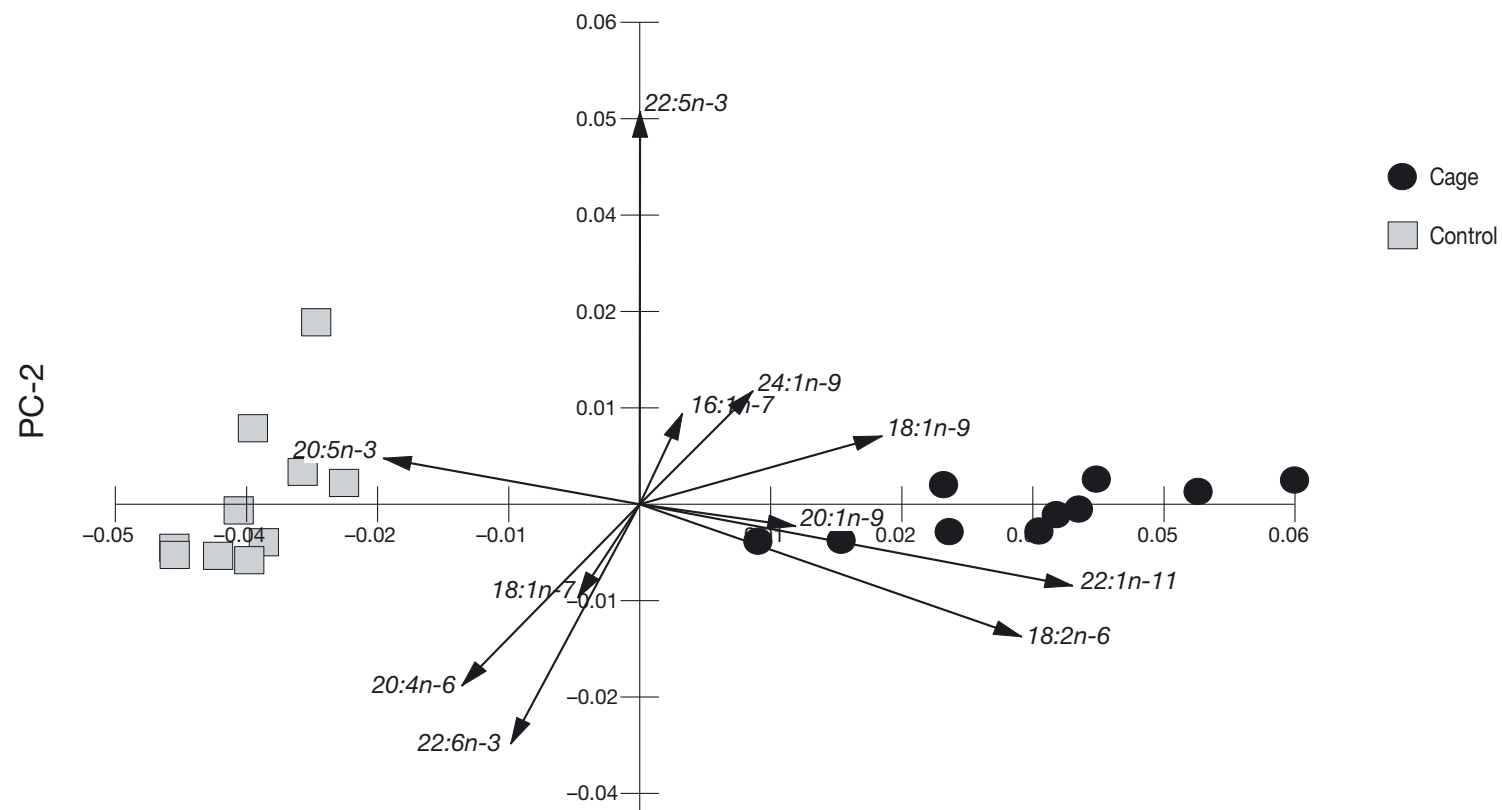

Fig. 4. Principal component analysis for fatty acid profiles (over $0.1 \%$ ) from the leg muscle of lobsters taken from the cage and control sites. Vectors for key fatty acids responsible for the grouping pattern are displayed 
indicated no significant differences for $\delta^{13} \mathrm{C}$ or $\delta^{15} \mathrm{~N}$ between cage and control sites for lobsters $(t=1.33$, $\mathrm{df}=5, \mathrm{p}=0.240$ ), and neither showed any similarity to the signatures for the salmon feed.

\subsection{Growth of lobsters}

An increase in CL was observed over the trial period at both cages and control sites. These were fitted to von Bertalanffy growth curves (Fig. 6) using calculated values of $K=0.0048, t_{0}=-32.08$ for the cage site and $K=0.0044, t_{0}=-0.4318$ for the control site. After Mauchly's test showing that the data conformed to sphericity ( $W=0.0224, \mathrm{p}=0.150)$, the repeated-measures ANOVA indicated significant growth in lobsters over the trial period $(F=77.5$, $\mathrm{p}<$ 0.001 ) at both sites, although there was no significant difference in lobster growth between the sites $(F=$ 20.9, $\mathrm{p}=0.149$ ).

\section{DISCUSSION}

The aim of this study was to determine if juvenile European lobsters would feed on waste from salmon cages in a coastal IMTA setup and assess if there was a subsequent impact on growth of the lobsters. Other studies have shown that the flow of wastes from coastal finfish aquaculture could potentially be used for aquaculture-based production of extractive species such as kelp (Fossberg et al. 2018) and bivalves (Lander et al. 2012). In this study, we evaluated a novel combination of co-cultured species wherein the juvenile lobsters would be used for restocking purposes rather than as an additional economic crop.

The results from the FA analysis showed that the content of OA (18:1n-9), LA (18:2n-6), ALA (18:3n-3), cetoleic acid (22:1n-11) and eicosenoic acid (20:1n-9), which were characteristic of the salmon feed used, were each significantly higher in the tissues of the lobsters located near the cages than in those at the control location. The PCA further confirmed these results, as the lobsters at the cage and control sites showed distinctly different FA profiles, which suggests different food sources. The FA profile of lobsters at the cage site was clearly influenced by the salmon feed, whereas at the control site, lobster nutrition was dominated by natural marine oils.

In contrast, stable isotope analysis of lobster leg muscle taken at the cage and control sites showed little difference in the $\delta^{15} \mathrm{~N}$ ratio between locations, nor

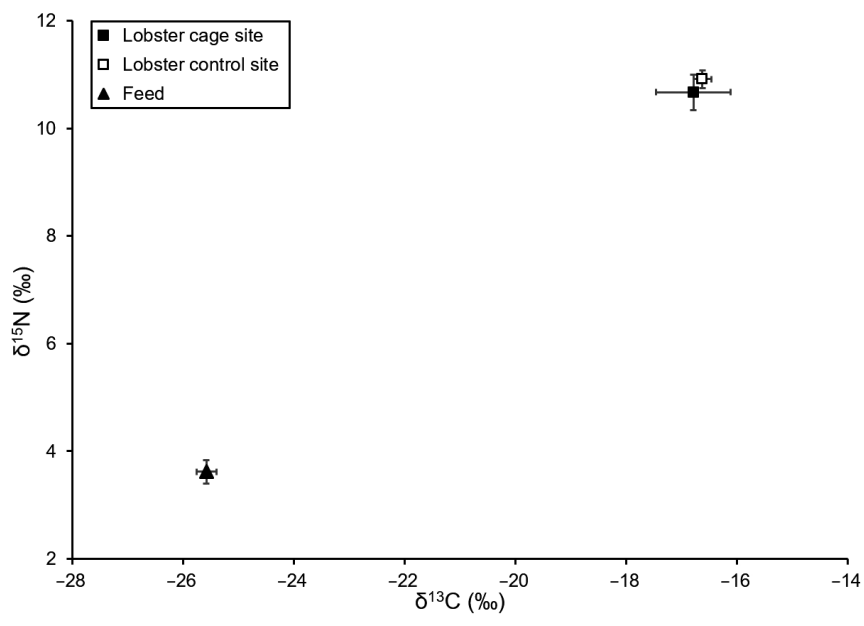

Fig. 5. Biplot of $\delta^{15} \mathrm{~N}$ and $\delta^{13} \mathrm{C}$ (mean $\pm \mathrm{SD}$ ) stable isotopes of lobster leg muscle and supplemented feed between cage and control stations at the end of the trial in March 2019

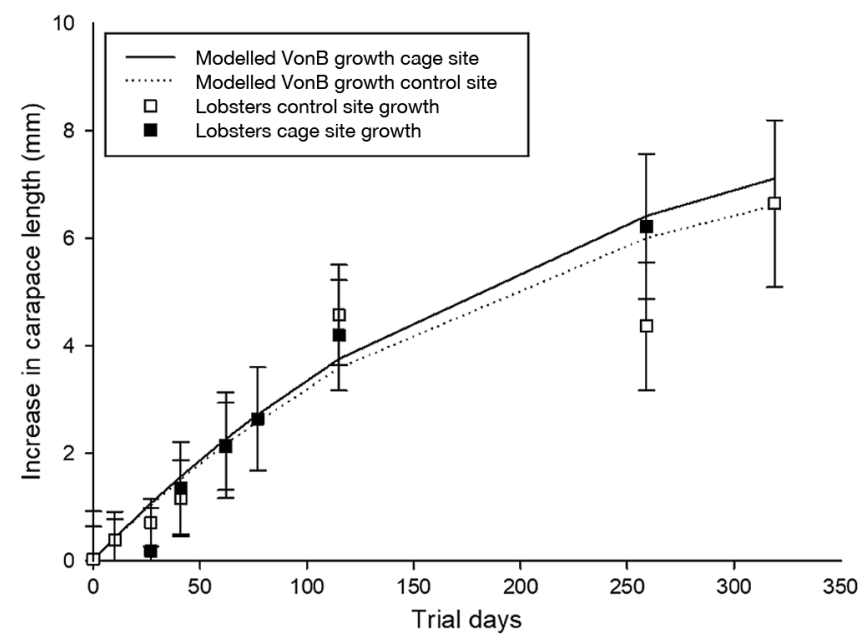

Fig. 6. Growth curves of lobsters between control and cage stations, based on measured values (mean $\pm \mathrm{SD}$ ). Von Bertalanffy growth functions plotted by trial day and increases in carapace length for $319 \mathrm{~d}$ of the trial. Parameters estimated for the cage site were $L_{\infty}=9.43, K=0.0044, t_{0}=-0.4318$, and control site $L_{\infty}=8.44, K=0.0048, t_{0}=-0.3208$

was there a similarity between the signature ratio for lobster tissue and salmon feed. There may be several reasons for the differences between the FA tracers and the stable isotope analysis. Bethoney et al. (2011) demonstrated that $\delta^{15} \mathrm{~N}$ values in lobster tissue reflect their long-term diet, so the time-period of our study may not have been long enough. Another consideration is that there may have been an insufficient amount of waste consumed to establish an isotopic signal, as lobsters are slow and periodic feeders (Bordner \& Conklin 1981). 
Based on their FA profiles, juvenile lobsters at the cage site consumed fish farm nutrient waste, although it was not clear if this was direct or indirect. The sizes of waste feed and faecal particles in the water column from the salmon cages were not measured in this experiment, but other studies have shown that suspended particulate organic matter originating from cages is often between 1 and $10 \mu \mathrm{m}$ (Lander et al. 2013) and up to $300 \mu \mathrm{m}$ (Law et al. 2014). As the internal mesh size of the SBCC structures was $2.5 \times 2.5 \mathrm{~mm}$ (Daniels et al. 2015), particles of waste this size could have entered the SBCC and been within the size range eaten directly by juvenile lobsters (Lavalli \& Barshaw 1989). Studies have demonstrated direct uptake of waste particles by consumer IMTA species (Handå et al. 2012, Bergvik et al. 2019). However, in the marine environment there will be a wider dietary choice and a complex food web. An in situ study showed that mussels did not directly assimilate wastes and had a selective diet, preferring other sources of food (Sanz-Lazaro \& Sanchez-Jerez 2017). Even within the SBCC system, there would be a dietary choice (Daniels et al. 2015), and the uptake of wastes by lobsters could have been indirect via fouling organisms.

Despite the differences in the FA profiles of the juvenile lobsters at the cage site and the reference site, there was no significant difference in growth. Information on growth rates of wild juvenile European lobsters is scarce (Mercer et al. 2001, Wahle et al. 2013), which prevents comparison to natural conditions. Stage IV is the first postlarval stage of the life cycle, and juvenile lobsters are transitioning to benthic organisms (Charmantier et al. 1991). Therefore, the position of the SBCC may not have been deep enough in the water column for their feeding behaviour and could have influenced the results, as other studies have shown that depth can be an important factor in IMTA systems (Sanz-Lazaro et al. 2018). There will always be multiple factors to consider in designing the optimal setup and there will often be trade-offs (Halswell et al. 2018). In this case, the scale of the experimental site meant there were limited options to position the SBCC within the waste stream of the fish cage. This study focussed on 1 cage site and 1 control site, but the dispersal of wastes around fish cages varies depending on site characteristics, and other locations may have had different results. Furthermore, this research used a pilot-scale experimental site, but the results may be different if the research was repeated at a fullscale commercial farm, as there would be higher volumes of waste.
Previous studies have demonstrated the advantage of acclimatising juvenile lobsters using in situ containers as a way of improving survivability (Beal et al. 2002, Perez Benavente et al. 2010, Beal \& Protopopescu 2012, Daniels et al. 2015, Halswell et al. 2016), and locating an SBCC next to salmon cages might offer additional shelter from storm events. However, it is also important to note that fish medication can be harmful to juvenile lobsters, and is often used to treat fish diseases (Burridge et al. 2014, Cresci et al. 2018). The effect of routine operations, such as disease treatment, on the different components of an IMTA system is not only an issue for lobsters and salmon, but is an essential consideration for any combination of species in an IMTA system. For example, lobsters could only be deployed at sites which use non-medicinal treatments.

The interaction between salmon cages and wild lobsters is an important area of research, especially in Canada where studies have explored the conflict over use of space between salmon farms and lobster fisheries (Walters 2007, Grant et al. 2019). In Canada and Norway, research has also focussed on the potential impact of medicinal treatments used for salmon aquaculture on lobsters (Burridge et al. 2014, Cresci et al. 2018). This present study focussed on potential benefits of having lobsters in an IMTA system alongside salmon cages prior to release into the wild for restocking purposes. The results clearly demonstrated utilisation of wastes from the salmon cages, but this had no obvious impact on growth. Other potential implications for lobster physiology, metabolic processes and behaviour were not explored. Sardenne et al. (2020) suggested that a diet shift toward waste fish feed may have an influence on reproductive success in some wild crustaceans. Therefore, although a trophic connection has been established within this system, further research and trials will be required to determine if a coastal salmon-lobster IMTA setup would be appropriate as a stage in lobster restocking programmes.

Acknowledgements. This work received funding from the European Union's Horizon 2020 research and innovation programme under Grant Agreement No. 678396 (Tools for Assessment and Planning of Aquaculture Sustainability, TAPAS). We are grateful to Dr. Ronan Browne, Bord Iascaigh Mhara and to the staff of the Marine Institute, particularly Frank Kane, for kindly providing administrative management and practical support through the sampling campaign. We also thank Dr. Carly Daniels and the staff of the National Lobster Hatchery for their support; the Nutritional Analytical Services, University of Stirling, for providing analytical facilities; and Maria Scolamacchia and Jessica Di Toro for providing training support on FA analysis. 


\section{LITERATURE CITED}

Abreu M, Varela D, Henríquez L, Villarroel A, Yarish C, Sousa-Pinto I, Buschmann A (2009) Traditional vs. integrated multi-trophic aquaculture of Gracilaria chilensis C. J. Bird, J. McLachlan \& E. C. Oliveira: productivity and physiological performance. Aquaculture 293: 211-220

Addison J, Lovewell S, Bannister R (1994) Growth, movement, recapture rate and survival of hatchery-reared lobsters (Homarus gammarus (Linnaeus, 1758)) released into the wild on the English east coast. Crustaceana 67: 156-172

Agnalt A, Grefsrud E, Farestveit E, Jørstad K (2017) Training camp - a way to improve survival in European lobster juveniles? Fish Res 186:531-537

Beal B, Protopopescu G (2012) Ocean-based nurseries for cultured lobster (Homarus americanus Milne Edwards) postlarvae: field experiments off the coast of eastern Maine to examine effects of flow and container size on growth and survival. J Shellfish Res 31:167-176

Beal B, Mercer JP, Conghaile AO (2002) Survival and growth of hatchery-reared individuals of the European lobster Homarus gammarus (L.), in field-based nursery cages on the Irish west coast. Aquaculture 210:137-157

Bergvik M, Stensås L, Handå A, Reitan K, Strand Ø, Olsen Y (2019) Incorporation of feed and fecal waste from salmon aquaculture in great scallops (Pecten maximus) co-fed by different algal concentrations. Front Mar Sci 5:524

Bethoney ND, Stokesbury KDE, Stevens BG, Altabet MA (2011) Bait and the susceptibility of American lobsters Homarus americanus to epizootic shell disease. Dis Aquat Org 95:1-8

Blomqvist S, Hakanson L (1981) A review on sediment traps in aquatic environments. Arch Hydrobiol 91:101-132

Blouin N, Xiugeng F, Peng J, Yarish C, Brawley S (2007) Seeding nets with neutral spores of the red alga Porphyra umbilicalis (L.) Kützing for use in integrated multi-trophic aquaculture (IMTA). Aquaculture 270: 77-91

Bordner CE, Conklin DE (1981) Food consumption and growth of juvenile lobsters. Aquaculture 24:285-300

Burridge LE, Lyons MC, Wong DKH, MacKeigan K, VanGeest JL (2014) The acute lethality of three anti-sea lice formulations: AlphaMax ${ }^{\circledR}$, Salmosan ${ }^{\circledR}$, and Interox ${ }^{\circledR}$ Paramove $^{\text {TM }} 50$ to lobster and shrimp. Aquaculture 420421:180-186

Charmantier G, Charmantier-Daures M, Aiken DE (1991) Metamorphosis in the lobster Homarus (Decapoda): a review. J Crustac Biol 11:481-495

* Chopin T, Cooper J, Reid G, Cross S, Moore C (2012) Openwater integrated multi-trophic aquaculture: environmental biomitigation and economic diversification of fed aquaculture by extractive aquaculture. Rev Aquacult 4: 209-220

Christie WW (1993) Preparation of derivatives of fatty acids for chromatograpgic analysis. In: Christie WW (ed) Advances in lipid methodology - two. Oily Press, Dundee, p 69-111

Clark KR, Gorley RN (2001) PRIMER v5: user manual/ tutorial. PRIMER_E, Plymouth

Colombo SM, Parrish CC, Whiticar MJ (2016) Fatty acid stable isotope signatures of molluscs exposed to finfish farming outputs. Aquacult Environ Interact 8:611-617

Coplen TB, Brand WA, Gehre M, Gröning M, Meijer HAJ,
Toman B, Verkouteren MR (2006) New guidelines for $\delta^{13} \mathrm{C}$ measurements. Anal Chem 78:2439-2441

Cresci A, Samuelsen OB, Durif CMF, Bjelland RM, Skiftesvik AB, Browman HI, Agnalt AL (2018) Exposure to teflubenzuron negatively impacts exploratory behaviour, leaning and activity of juvenile European lobster (Homarus gammarus). Ecotoxicol Environ Saf 160: 216-221

* Daniels C, Wills B, Ruiz-Perez M, Miles E, Wilson R, Boothroyd D (2015) Development of sea-based container culture for rearing European lobster (Homarus gammarus) around South West England. Aquaculture 448: 186-195

* Deudero S, Díaz D, Tor A, Mallol S, Goñi R (2012) Isotopic fractionation in wild and captive European spiny lobsters (Palinurus elephas). J Crustac Biol 32:421-424

* Drengstig A, Bergheim A (2013) Commercial land-based farming of European lobster (Homarus gammarus (L.)) in recirculating aquaculture system (RAS) using a single cage approach. Aquacult Eng 53:14-18

Ellis CD, Hodgson DJ, Daniels CL, Boothroyd DP, Bannister RCA, Griffiths AGF (2015) European lobster stocking requires comprehensive impact assessment to determine fishery benefits. ICES J Mar Sci 72(Suppl 1):i35-i48

* Fernandez-Jover D, Sanchez-Jerez P, Bayle-Sempere J, Arechavala-Lopez P, Martinez-Rubio L, Jimenez JAL, Lopez FJM (2009) Coastal fish farms are settlement sites for juvenile fish. Mar Environ Res 68:89-96

* Fernandez-Jover D, Arechavala-Lopez P, Martinez-Rubio L, Tocher DR and others (2011) Monitoring the influence of marine aquaculture on wild fish communities: benefits and limitations of fatty acid profiles. Aquacult Environ Interact 2:39-47

Folch J, Lees M, Sloane Stanley GH (1957) A simple method for the isolation and purification of total lipids from animal tissues. J Biol Chem 226:497-509

Fossberg J, Forbord S, Broch OJ, Malzahn AM and others (2018) The potential for upscaling kelp (Saccharina latissima) cultivation in salmon-driven integrated multitrophic aquaculture (IMTA). Front Mar Sci 5:418

* George EM, Parrish CC (2015) Invertebrate uptake of lipids in the vicinity of Atlantic salmon (Salmo salar) aquaculture sites in British Columbia. Aquacult Res 46: 1044-1065

* Grant J, Simone M, Daggett T (2019) Long-term studies of lobster abundance at a salmon aquaculture site, eastern Canada. Can J Fish Aquat Sci 76:1096-1102

*Halswell P, Daniels CL, Johanning L (2016) Sea based container culture (SBCC) hydrodynamic design assessment for European lobsters (Homarus gammarus). Aquacult Eng 74:157-173

* Halswell P, Daniels C, Johanning L (2018) Framework for evaluating external and internal parameters associated with Sea Based Container Culture (SBCC): towards understanding rearing success in European lobsters (Homarus gammarus). Aquacult Eng 83:109-119

* Handå A, Ranheim A, Olsen AJ, Altin D, Reitan KT, Olsen Y, Reinertsen H (2012) Incorporation of salmon fish feed and feces components in mussels (Mytilus edulis): implications for integrated multi-tropic aquaculture in cooltemperature North Atlantic waters. Aquaculture 370371:40-53

*Henderson RJ, Forest DAM, Black KD, Park MT (1997) The lipid composition of sealoch sediments underlying salmon cages. Aquaculture 158:69-83 
Irisarri J, Fernandez-Reiriz MJ, Labarta U, Cranford PJ, Robinson MC (2015) Availability and utilization of waste fish feed by mussels Mytilus edulis in a commercial integrated multi-trophic aquaculture (IMTA) system: a multi-indicator assessment approach. Ecol Indic 48: 673-686

Lander TR, Robinson SMC, MacDonald BA, Martin JD (2012) Enhanced growth rates and condition index of blue mussels (Mytilus edulis) held at integrated multitrophic aquaculture sites in the Bay of Fundy. J Shellfish Res 31:997-1007

* Lander TR, Robinson SMC, MacDonald BA, Martin JD (2013) Characterization of the suspended organic particles released from salmon farms and their potential as a food supply for the suspension feeder, Mytilus edulis in integrated multi-trophic aquaculture (IMTA) systems. Aquaculture 406-407:160-171

Lavalli KL, Barshaw DE (1989) Post-larval American lobsters (Homarus americanus) living in burrows may be suspension feeding. Mar Behav Physiol 15:255-264

Kaw BA, Hill PS, Maier I, Milligan TG, Page F (2014) Size, settling velocity and density of small suspended particles at an active salmon aquaculture site. Aquacult Environ Interact 6:29-42

* Marín Leal JCM, Dubois S, Orvain F, Galois R and others (2008) Stable isotopes $\left(\delta^{13} \mathrm{C}, \delta^{15} \mathrm{~N}\right)$ and modelling as tools to estimate the trophic ecology of cultivated oysters in two contrasting environments. Mar Biol 153: 673-688

* Mercer JP, Bannister RCA, van der Meeren GI, Debuse V and others (2001) An overview of the LEAR (Lobster Ecology and Recruitment) project: results of field and experimental studies on the juvenile ecology of Homarus gammarus in cobble. Mar Freshw Res 52:1291-1301

Navarrete-Mier F, Sanz-Lázaro C, Marín A (2010) Does bivalve mollusc polyculture reduce marine fin fish farming environmental impact? Aquaculture 306:101-107

Nillos Kleiven P, Espeland S, Olsen E, Abesamis R, Moland E, Kleiven A (2019) Fishing pressure impacts the abundance gradient of European lobsters across the borders of a newly established marine protected area. Proc R Soc B 286:20182455

Olsen SA, Ervik A, Grahl-Nielsen O (2012) Tracing fish farm waste in the northern shrimp Pandalus borealis (Krøyer, 1838) using lipid biomarkers. Aquacult Environ Interact 2:133-144

* Paulet Y, Lorrain A, Richard J, Pouvreau S (2006) Experimental shift in diet $\delta^{13} \mathrm{C}$ : a potential tool for ecophysiological studies in marine bivalves. Org Geochem 37 : 1359-1370

Perez Benavente G, Uglem I, Browne R, Marino Balsa C (2010) Culture of juvenile European lobster (Homarus gammarus (L.)) in submerged cages. Aquacult Int 18: 1177-1189

Qi H, Coplen T, Geilmann H, Brand W, Böhlke J (2003) Two new organic reference materials for $\delta^{13} \mathrm{C}$ and $\delta^{15} \mathrm{~N}$ measurements and a new value for the $\delta^{13} \mathrm{C}$ of NBS 22 oil. Rapid Commun Mass Spectrom 17:2483-2487

Redmond K, Magnesen T, Hansen P, Strand $\varnothing$, Meier S (2010) Stable isotopes and fatty acids as tracers of the assimilation of salmon fish feed in blue mussels (Mytilus edulis). Aquaculture 298:202-210

Editorial responsibility: Philippe Archambault, Rimouski, Québec, Canada
Sanz-Lazaro C, Sanchez-Jerez P (2017) Mussels do not directly assimilate fish farm wastes: shifting the rationale of integrated multi-trophic aquaculture to a broader scale. J Environ Manag 201:82-88

* Sanz-Lazaro C, Fernandez-Gonzalez V, Arechavala-Lopez P, Izquierdo-Gomez D, Martinez-Garcia E, SanchezJerez P (2018) Depth matters for bivalve culture in integrated multitrophic aquaculture (IMTA) and other polyculture strategies under non-eutrophic conditions. Aquacult Int 26:1161-1170

Warà G, Zenone A, Tomasello A (2009) Growth of Mytilus galloprovincialis (Mollusca, Bivalvia) close to fish farms: a case of integrated multi-trophic aquaculture within the Tyrrhenian Sea. Hydrobiologia 636:129-136

* Sardenne F, Simard M, Robinson SMC, McKindsey CW (2020) Consumption of organic wastes from coastal salmon aquaculture by wild decapods. Sci Total Environ 711:134863

KSchmalenbach I, Mehrtens F, Janke M, Buchholz F (2011) A mark-recapture study of hatchery-reared juvenile European lobsters, Homarus gammarus, released at the rocky island of Helgoland (German Bight, North Sea) from 2000 to 2009. Fish Res 108:22-30

Sokal RR, Rohlf FJ (1995) Biometry. Freeman, New York, NY

Sprague M, Dick J, Tocher D (2016) Impact of sustainable feeds on omega-3 long-chain fatty acid levels in farmed Atlantic salmon, 2006-2015. Sci Rep 6:21892

* Telfer TC, Baird DJ, McHenery JG, Stone J, Sutherland I, Wislocki P (2006) Environmental effects of the anti-sea lice (Copepoda: Caligidae) therapeutant emamectin benzoate under commercial use conditions in the marine environment. Aquaculture 260:163-180

Von Bertalanffy L (1938) A quantitative theory of organic growth (inquiries on growth laws. II). Human Biol 10: 181-213

Wahle RA, Castro KM, Tully O, Cobb JS (2013) Homarus. In: Phillips BF (ed) Lobsters: biology, management, aquaculture and fisheries, $2^{\text {nd }}$ edn. John Wiley \& Sons, New York, NY, p 221-258

*Walters BB (2007) Competing use of marine space in a modernizing fishery: salmon farming meets lobster fishing on the Bay of Fundy. Can Geogr 51:139-159

*Wang X, Olsen LM, Reitan KI, Olsen Y (2012) Discharge of nutrient wastes from salmon farms: environmental effects, and potential for integrated multi-trophic aquaculture. Aquacult Environ Interact 2:267-283

White CA, Bannister RJ, Dworjanyn SA, Husa V, Nichols PD, Kutti T, Dempster T (2017) Consumption of aquaculture waste affects the fatty acid metabolism of a benthic invertebrate. Sci Total Environ 586:1170-1181

White C, Woodcock S, Bannister R, Nichols P (2019) Terrestrial fatty acids as tracers of finfish aquaculture waste in the marine environment. Rev Aquacult 11:133-148

*Wilson E (2008) Homarus gammarus. Common lobster. In: Tyler-Walters H, Hiscock K (eds) Marine Life Information Network. Marine Biological Association of the United Kingdom. https://www.marlin.ac.uk/species/detail/1171 (accessed June 8)

Woodcock SH, Strohmeier T, Strand Ø, Olsen SA, Bannister RJ (2018) Mobile epibenthic fauna consume organic waste from coastal fin-fish aquaculture. Mar Environ Res $137: 16-23$

Submitted: January 27, 2020; Accepted: September 7, 2020

Proofs received from author(s): October 30, 2020 